\title{
Multiple-endpoint in vitro carcinogenicity test in human cell line TK6 distinguishes carcinogens from non-carcinogens and highlights mechanisms of action
}

\author{
Katherine E. Chapman ${ }^{1}$ (D) Eleanor C. Wilde ${ }^{1}$. Fiona M. Chapman ${ }^{1}$. Jatin R. Verma ${ }^{1}$. Ume-Kulsoom Shah ${ }^{1}$. \\ Leanne M. Stannard ${ }^{1}$. Anna L. Seager ${ }^{1}$. James A. Tonkin ${ }^{2} \cdot$ M. Rowan Brown ${ }^{2}$. Ann T. Doherty ${ }^{3}$. \\ George E. Johnson ${ }^{1}$. Shareen H. Doak ${ }^{1}$. Gareth J. S. Jenkins ${ }^{1}$
}

Received: 19 June 2020 / Accepted: 2 September 2020 / Published online: 10 September 2020

(c) The Author(s) 2020

\begin{abstract}
Current in vitro genotoxicity tests can produce misleading positive results, indicating an inability to effectively predict a compound's subsequent carcinogenic potential in vivo. Such oversensitivity can incur unnecessary in vivo tests to further investigate positive in vitro results, supporting the need to improve in vitro tests to better inform risk assessment. It is increasingly acknowledged that more informative in vitro tests using multiple endpoints may support the correct identification of carcinogenic potential. The present study, therefore, employed a holistic, multiple-endpoint approach using low doses of selected carcinogens and non-carcinogens $(0.001-770 \mu \mathrm{M})$ to assess whether these chemicals caused perturbations in molecular and cellular endpoints relating to the Hallmarks of Cancer. Endpoints included micronucleus induction, alterations in gene expression, cell cycle dynamics, cell morphology and bioenergetics in the human lymphoblastoid cell line TK6. Carcinogens ochratoxin A and oestradiol produced greater Integrated Signature of Carcinogenicity scores for the combined endpoints than the "misleading" in vitro positive compounds, quercetin, 2,4-dichlorophenol and quinacrine dihydrochloride and toxic non-carcinogens, caffeine, cycloheximide and phenformin $\mathrm{HCl}$. This study provides compelling evidence that carcinogens can successfully be distinguished from non-carcinogens using a holistic in vitro test system. Avoidance of misleading in vitro outcomes could lead to the reduction and replacement of animals in carcinogenicity testing.
\end{abstract}

Keywords In vitro $\cdot$ Carcinogenicity testing $\cdot$ Genotoxicity $\cdot$ Multiple endpoints

\section{Introduction}

This publication is dedicated to the memory of Dr. Ellie Verma (née Wilde) (1990-2019), who contributed to this project.

Electronic supplementary material The online version of this article (https://doi.org/10.1007/s00204-020-02902-3) contains supplementary material, which is available to authorized users.

Katherine E. Chapman

K.E.Chapman@swansea.ac.uk

1 In Vitro Toxicology Group, Institute of Life Science 1, Swansea University Medical School, Swansea University, Singleton Campus, Swansea SA2 8PP, UK

2 College of Engineering, Swansea University, Bay Campus, Swansea SA1 8EN, UK

3 Discovery Safety, AstraZeneca, DSM, Darwin Building, Cambridge Science Park, Milton Road, Cambridge CB4 0WG, UK
Thousands of new chemical entities (NCEs) are generated each year, and all require initial safety testing to predict their human health implications. Exposure to certain agents can increase human cancer risk, due to genotoxicity or other mechanisms of carcinogenesis. Carcinogenicity assessment of NCEs is, therefore, necessary prior to chemical advancement within the pharmaceutical, food, agriculture, and general manufacturing industries.

Chemical safety assessment generally follows a tiered route, where initial in vitro genotoxicity test results determine whether subsequent in vivo genotoxicity and carcinogenicity investigation is performed (Rovida et al. 2015). It is well accepted by regulators that in vitro tests demonstrate low specificity, failing to successfully distinguish carcinogens from non-carcinogens (Pfuhler et al. 2011; Rovida et al. 2015). There are, therefore, two classes of 
in vitro positives: true positives, which are in vitro positives that cause carcinogenesis in in vivo follow-up tests, and 'misleading' positives, which are positive in vitro yet negative when subsequently tested in vivo. Such misleading positives are, therefore, only identified when the results are not replicated in follow-up in vivo carcinogenicity testing (Fowler et al. 2012a; Kirkland et al. 2005a, b; Kirkland et al. 2007; Thybaud et al. 2007). Factors such as the choice of cell type and excessive toxicity from high doses can affect the frequency of misleading positive results from in vitro genotoxicity tests (Fowler et al. 2012a, b, 2014; Shah et al. 2016). The choice of treatment type, number of test concentrations and timescale in vitro will also impact on the outcome for certain endpoints at low doses (Chapman et al. 2015, 2020).

High misleading positive rates have important consequences, including hindering the development of many chemicals with beneficial applications, such as in products and treatments (Fowler et al. 2012a). A second serious consequence of such misleading positives is the required performance of unnecessary animal testing to further investigate positive in vitro results that are later determined to be artefactual (Pfuhler et al. 2009). Improving in vitro tests for carcinogenicity prediction is, therefore, imperative for alignment with the 3 Rs principle (Burden et al. 2015) and, therefore, avoiding ethical issues and resources associated with in vivo testing. Furthermore, initiatives such as Toxicity Testing in the Twenty-First Century are recognising that the use of human cell-based in vitro testing may confer greater human relevance than animal-based tests (Adeleye et al. 2015; Council 2007).

The advantages of multi-endpoint in vitro approaches for accurate prediction of in vivo carcinogenicity are increasingly being recognised (Benigni 2014; Bourcier et al. 2015; Breheny et al. 2011; McKim and James 2010). The parallel assessment of multiple, holistic endpoints may enable a broad range of carcinogenic mechanisms to be monitored and link to adverse outcome pathways (AOPs) (Burden et al. 2015). Previously, we have demonstrated that integrated in vitro endpoints show promise in distinguishing genotoxic carcinogens from non-genotoxic carcinogens, with results also correlating well with in vivo data (Wilde et al. 2018).

While in vitro genotoxicity tests have been studied previously for their ability to identify carcinogens and non-carcinogens accurately (Kirkland et al. 2005a, b; Kirkland et al. 2006), holistic approaches have not been comprehensively validated. Indeed, using multiple genotoxicity test systems has been demonstrated to increase sensitivity (Kirkland et al. $2005 \mathrm{a}, \mathrm{b}$ ); this supports the use of multiple endpoints to provide more information on compounds' biological effects. It is possible that the traditional genotoxicity endpoints alone have limited relevance for cancer prediction, and cancerrelevant endpoints should instead be pursued, given that the next test stage usually involves carcinogenicity assessment (Steiblen et al. 2020).

The objective of the present study, therefore, was to establish a more informative in vitro test that could increase confidence in in vitro genotoxicity data, and potentially be incorporated into current test batteries. This was achieved by evaluating, for the first time, whether our multi-endpoint in vitro carcinogenicity approach could correctly predict in vivo carcinogenicity outcomes for both carcinogens and non-carcinogens. The chemicals selected for study are summarised in Table 1. Based on the existing literature, two carcinogens, ochratoxin A (OTA) and 17-ß-oestradiol (oestradiol), were selected to further evaluate the test strategy for carcinogens of which the mechanism is not fully understood. As well as the carcinogens, two different types of 'noncarcinogens' were tested to validate our holistic approach; 'misleading' in vitro positives and toxic non-carcinogens. The three misleading in vitro positive compounds tested were quercetin, 2,4-dichlorophenol (2,4-DCP) and quinacrine dihydrochloride (QDH) (Kirkland et al. 2008). While quercetin has often been referred to as a misleading in vitro positive, there is also a $\mathrm{TD}_{50}$ value available suggesting that it is not necessarily a misleading positive (Table 2). The small number of studies that did produce positive in vivo carcinogenicity results with quercetin have, however, been heavily criticised due to study design (Pamukcu et al. 1980; Program 1992). The three non-carcinogens selected were caffeine, cycloheximide and phenformin $\mathrm{HCl}$ (Kirkland et al. 2016; Bryce et al. 2017). By comparing the overall outcomes for the carcinogens with non-carcinogens, we can determine the suitability of our test strategy for correctly identifying new chemicals with carcinogenic potential.

\section{Materials and methods}

\section{Chemicals}

Test chemicals were purchased from Sigma-Aldrich and stored according to the manufacturer's instructions. OTA, QDH and quercetin were dissolved/diluted in dimethyl sulfoxide (DMSO) (Fisher Scientific), whereas 2,4-DCP, caffeine, cycloheximide and phenformin $\mathrm{HCl}$ were dissolved/ diluted in $\mathrm{dH}_{2} \mathrm{O}$. Oestradiol was dissolved/diluted in ethanol. Final concentrations of test chemicals within cell cultures ranged from 0 to $770 \mu \mathrm{M}$, and these were selected based on toxicity, as outlined below. Safety precautions, such as PPE and suitable waste disposal, were taken to protect users from exposure to hazardous compounds. 
Table 1 A summary of the compounds used in the study

\begin{tabular}{|c|c|c|c|}
\hline Group & Compound name & Source of exposure/application & $\begin{array}{l}\text { Cellular mechanisms/carcinogenic potential } \\
\text { (where applicable) }\end{array}$ \\
\hline \multirow[t]{2}{*}{ Carcinogen } & Ochratoxin A (OTA) & $\begin{array}{l}\text { Food contaminant (cereal, wine, coffee) } \\
\text { (Heussner and Bingle 2015) }\end{array}$ & $\begin{array}{l}\text { IARC Group II carcinogen. Genotoxic } \\
\text { (nephro)carcinogen (Boorman 1989; Dai } \\
\text { et al. 2003; El Adlouni et al. 2000; Pfohl- } \\
\text { Leszkowicz and Castegnaro 2005) }\end{array}$ \\
\hline & $\beta$-oestradiol & Steroid hormone (reproductive) & $\begin{array}{l}\text { IARC Group I carcinogen. Evidence for } \\
\text { genotoxic and non-genotoxic mechanisms } \\
\text { of carcinogenesis (Bryce et al. 2017; } \\
\text { Hernández et al. 2013) }\end{array}$ \\
\hline \multirow[t]{3}{*}{ Misleading in vitro positives } & Quercetin & $\begin{array}{l}\text { Most abundant flavonoid in the human diet } \\
\text { (Casella et al. 2014) }\end{array}$ & $\begin{array}{l}\mathrm{TD}_{50} \text { value suggests carcinogenic potential } \\
\text { (Table 2). Consistent misleading in vitro } \\
\text { positive but full mechanism not known }\end{array}$ \\
\hline & 2,4-DCP & $\begin{array}{l}\text { Herbicide used in agriculture (Munro et al. } \\
\text { 1992) }\end{array}$ & $\begin{array}{l}\text { Possibly superoxide radical generation by } \\
\text { decreasing superoxide dismutase in vitro } \\
\text { (Bukowska 2003; Garg et al. 2001) }\end{array}$ \\
\hline & $\begin{array}{l}\text { Quinacrine dihydro- } \\
\text { chloride (QDH) }\end{array}$ & $\begin{array}{l}\text { Antimalarial drug, non-surgical female } \\
\text { sterilisation (Clarke et al. 2001) }\end{array}$ & $\begin{array}{l}\text { Evidence of in vitro DNA intercalation but is } \\
\text { not carcinogenic (Clarke et al. 2001) }\end{array}$ \\
\hline \multirow[t]{3}{*}{ Toxic non-carcinogens } & Cycloheximide & Antibiotic & $\begin{array}{l}\text { Protein synthesis inhibitor that causes cyto- } \\
\text { toxicity (Youngblom et al. 1989) }\end{array}$ \\
\hline & Caffeine & Stimulant & $\begin{array}{l}\text { Mitochondria-dependent apoptosis, ROS } \\
\text { inducer that causes cytotoxicity (Bryce } \\
\text { et al. 2017) }\end{array}$ \\
\hline & Phenformin $\mathrm{HCl}$ & $\begin{array}{l}\text { Biguanide antidiabetic (Kirkland et al. } \\
\text { 2016) }\end{array}$ & $\begin{array}{l}\text { Non-carcinogen, negative in vivo (Kirkland } \\
\text { et al. 2016) }\end{array}$ \\
\hline
\end{tabular}

\section{Selection of doses for study}

Table $2 \mathrm{TD}_{50}$ data (Gold database, Lhasa database) for rodent carcinogenicity (where applicable) for the test compounds

\begin{tabular}{ll}
\hline Chemical & $\mathrm{TD}_{50}(\mathrm{mg} / \mathrm{kg} /$ day $)$ \\
\hline OTA & 0.136 \\
Oestradiol & 1.0 \\
Quercetin & 10.1 \\
$2,4-D C P$ & Negative \\
Caffeine & Negative \\
Cycloheximide & Negative/ND \\
Phenformin $\mathrm{HCl}$ & Negative/ND \\
QDH & Not available/ND \\
\hline
\end{tabular}

$N D$ no data

\section{Cell culture}

The human lymphoblastoid cell line, TK6 (ECACC), was cultured in RPMI 1640 Medium (Life Technologies) supplemented with $10 \%$ donor horse serum (BDGentest) and $2 \mathrm{mM}$ L-glutamine (Life Technologies). The cells were maintained in culture between $1 \times 10^{5}$ and $1 \times 10^{6}$ cells/ $\mathrm{ml}$. For all studies, cells were seeded at a density of $1 \times 10^{5}$ cells/ml and cultured for $24 \mathrm{~h}$ prior to treatment commencement $\left(37^{\circ} \mathrm{C}, 5 \% \mathrm{CO}_{2}\right)$.
Doses were selected based on initial relative population doubling (RPD) data to ensure that excessive toxicity ( $>50 \%$ RPD) did not occur. Following this, MN datasets were generated based on the defined dose range, and from $\mathrm{MN}$ data, a selected number of doses were chosen for study with further endpoints. If the chemical was positive in the $\mathrm{MN}$ assay, the NOEL (no observed effect level), LOEL (lowest observed effect level) and the dose producing 50\% reduction in RPD was tested. If the chemical tested negative in the MN assay, doses within the initial dose range tested were then taken forward. The multiple-dose approach allowed dose-dependent trends to be identified, as well as provide an indication of safe exposure levels.

\section{Cytokinesis-blocked micronucleus assay}

Frequency of chromosome damage in the form of micronuclei was analysed using the cytokinesis-blocked micronucleus (CBMN) assay. The protocol for Metafer analysis was as published previously (Seager et al. 2014). Timepoints used were either $4 \mathrm{~h}$ treatment $+23 \mathrm{~h}$ recovery, or $23 \mathrm{~h}$ treatment $+23 \mathrm{~h}$ recovery, unless otherwise stated. Cytochalasin B $(4.5 \mu \mathrm{g} / \mathrm{ml})$ was added at the commencement of the recovery period and this ensured that cells divided following the treatment period to allow observation of micronuclei 
(Fenech et al. 2003). For all other endpoints, $0 \mathrm{~h}$ recovery time was allowed following treatment to maximise the window for observing treatment-specific cell and molecular effects. A total of 9000 binucleate cells were scored per treatment per replicate. Relative population doubling (RPD) (\%) (Fellows et al. 2008; Lorge et al. 2008) was measured in parallel cultures in the absence of cytochalasin $\mathrm{B}$, with $<50 \%$ reduction in RPD relative to the vehicle control aimed for, in line with OECD requirements.

\section{Protein isolation and immunoblotting}

To investigate $\mathrm{p} 53$ and phospho-p53 expression following treatment with test chemicals, protein isolation and immunoblotting were performed. A previously published method was followed (Brusehafer et al. 2014).

\section{Gene expression analysis}

A shortlist of genes for qRT-PCR analysis was generated via mRNA microarray chip technology (Illumina) to measure genome-wide transcriptome alterations, as detailed by Wilde et al. (2018). qRT-PCR was completed for cyclindependent kinase inhibitor 1A (CDKNIA), choline kinase alpha (CHKA) and serine/threonine protein kinase (SGK1). A previously published method was followed (Brusehafer, et al. 2014). Primer sequences are available in Wilde et al. (2018).

\section{Cell cycle analysis}

Flow cytometry assessed nucleated cells in the cell cycle phases of G1, S and G2/M after $4 \mathrm{~h}$ or $23 \mathrm{~h}$. Samples were harvested using the In Vitro MicroFlow Micronucleus Analysis Kit (Litron Laboratories), as per the manufacturer's instructions. Samples were analysed using the BD Facs Aria Flow Cytometer (BD Biosciences), with FacsDiva software (BD Biosciences), as described in Verma et al. (2017). Appropriate gating was applied to segregate the cell populations within the respective cell cycle phases and a total of 36,000 events were analysed across three replicates for each treatment.

\section{Cell and nuclear morphology analysis}

Cell and nuclear morphology analysis was performed using the INCell Analyzer 2000 followed by a MATLAB-based script to identify cells and nuclei from captured images. The full methodology was previously outlined by Wilde et al. (2018). For the toxic non-carcinogens, the CellProfiler 2.2.0 software was used to obtain equivalent data on cell and nuclear morphology.

\section{Bioenergetics studies}

The Seahorse Bioanalyzer (Agilent) was used to measure bioenergetic flux in control and treated samples, to establish whether chemicals influenced mitochondrial activity. Seahorse analyses were performed as outlined by Wilde et al. (2018).

\section{ToxPi $^{\mathrm{Tm}}$ graphical user interface}

The Toxicological Prioritization Index (ToxPi ${ }^{\mathrm{TM}}$ ) graphical user interface (GUI) was used to generate overall profiles for the eight test chemicals (Reif et al. 2013). 'Slices' of the pie chart were weighted as necessary and the length of the radius was proportional to the magnitude of the change relative to the vehicle control. The concentration of chemical inducing an approximately 50\% reduction in RPD relative to the vehicle control, or the highest concentration administered, was used to generate fold-change values relative to the control. The selection of the dose eliciting approximately $50 \%$ RPD was performed based on visual inspection of the original dose-response (Fig. 1). This dose was chosen with the objective of maximising the differentiation between carcinogens and non-carcinogens, given that the effect would be greatest at the highest concentration. The square root of all values was taken, and scores were scaled sufficiently to enable clear visualisation of all segments.

\section{Statistical analysis}

Three biological replicates (except where indicated) were performed as independent experiments on separate days, with separate stock vials of cells/chemicals. Error bars represent standard deviation. Data were tested for normality (Shapiro-Wilk test) and homogeneity of variance (Levene's statistic) and transformed where appropriate, prior to statistically significant changes being determined using a one-way ANOVA with appropriate post hoc tests depending on initial test outcomes. A mean-centering approach was used for the qRT-PCR data (Willems et al. 2008), prior to statistical analysis. Outcomes of $p \leq 0.05$ for two-sided tests were deemed statistically significant. On all figures, statistically significant changes relative to the vehicle control were indicated using asterisks; $* p \leq 0.05 ; * * p \leq 0.01 ; * * * p \leq 0.001$.

\section{Results}

The present study applied an integrated test approach for carcinogenicity prediction within an in vitro system to observe for the first time whether carcinogens could be distinguished from non-carcinogens. Holistic endpoint analysis was investigated using eight test chemicals: carcinogens, OTA and 
Fig. 1 The cytokinesis-blocked micronucleus (CBMN) assay $(4 \mathrm{~h} / 23 \mathrm{~h}$ treatment $+23 \mathrm{~h}$ recovery) was used to assess whether test compounds induced genotoxicity. The percentage of binucleated cells containing micronuclei $(\mathrm{MN}$, $\%$ ) (black lines) and relative population doubling (RPD, \%) (grey lines) are presented for the chemicals $(n=2, n=3)$. Statistically significant results from the statistical analysis (Dunnett's tests) are indicated by $p$ values, where $* p<0.05$, $* * p<0.01$, *** $p<0.001$ (color figure online)

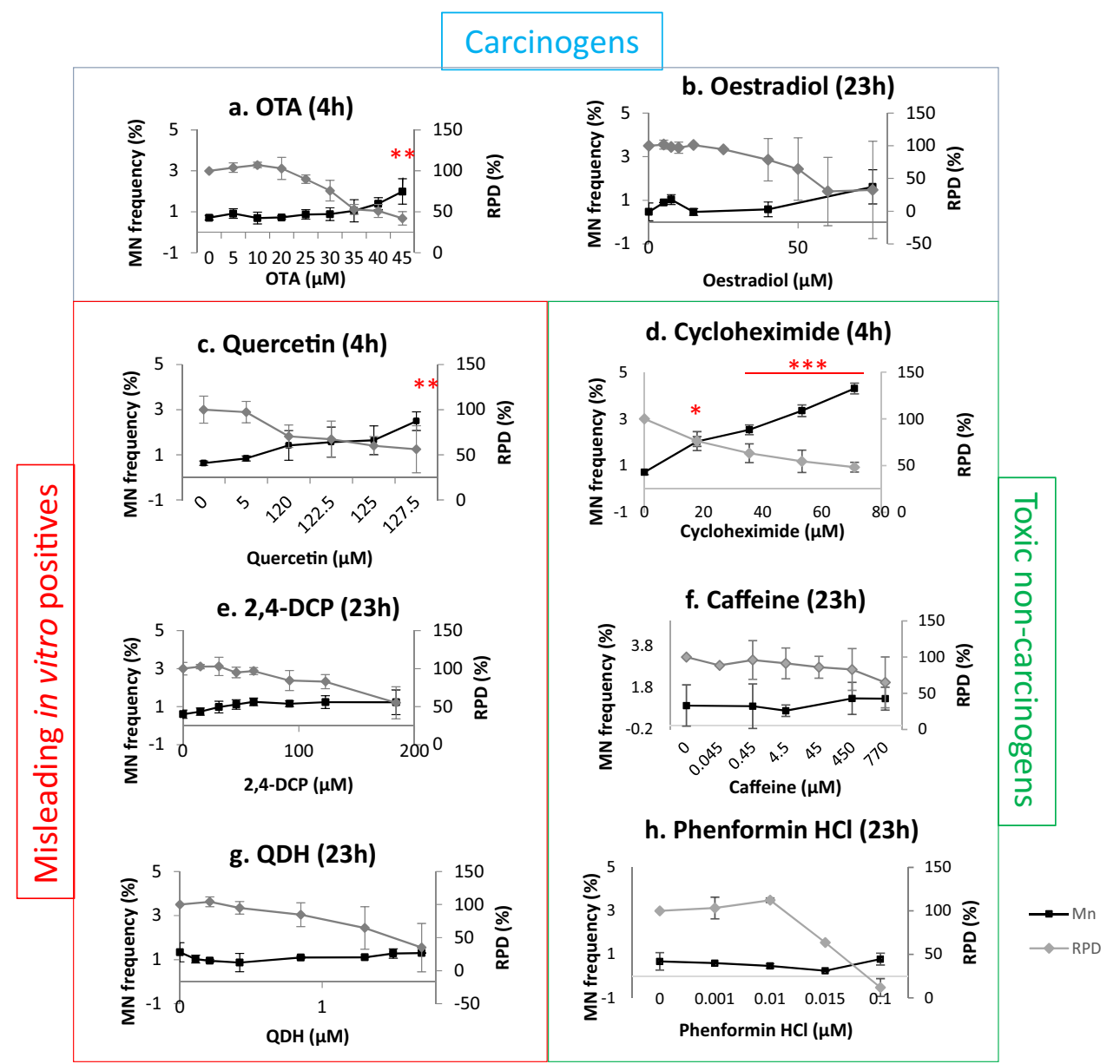

oestradiol; misleading in vitro positives, 2,4-DCP, quercetin and QDH; non-carcinogens, caffeine, cycloheximide and phenformin $\mathrm{HCl}$.

\section{Multiple test chemicals caused MN formation}

The CBMN assay was used to generate genotoxicity dose-responses for all test chemicals (Fig. 1). Up to a $50 \%$ decrease in concurrent RPD was tolerated, to avoid secondary toxicity associated with higher concentrations. Chemicals were tested initially using a $4 \mathrm{~h}$ treatment with $23 \mathrm{~h}$ recovery; if the result after $4 \mathrm{~h}+23 \mathrm{~h}$ was negative, the chemical exposure was then repeated for $23 \mathrm{~h}+23 \mathrm{~h}$. After $4 \mathrm{~h}$, OTA produced statistically significant increases in $\mathrm{MN}$ frequency relative to the vehicle control. For OTA, the increase occurred at a concentration inducing an approximately $50 \%$ reduction in RPD $(45 \mu \mathrm{M})$. Oestradiol produced a negative result after the $4 \mathrm{~h}$ and $23 \mathrm{~h}$ treatments, although was previously found to be positive in MCL-5 cells for an extended treatment period of $48 \mathrm{~h}+23 \mathrm{~h}$ (Chapman 2018). To determine whether the $23 \mathrm{~h}$ result was a false negative, the longer exposure of $48 \mathrm{~h}+23 \mathrm{~h}$ recovery was performed. Similar concentrations of oestradiol were used for $23 \mathrm{~h}$ and
$48 \mathrm{~h}$, given that the elongated exposure did not result in considerably elevated cytotoxicity. This resulted in a positive response for micronucleus induction for oestradiol at concentrations of $40 \mu \mathrm{M}$ and higher (Online resource 1).

Quercetin showed genotoxic activity in this study after $4 \mathrm{~h}$ treatment at $127.5 \mu \mathrm{M}$ only (50\% RPD). Cycloheximide produced a statistically significant increase at all concentrations tested following $4 \mathrm{~h}$ exposure. While cycloheximide is toxic, it is not always considered to be genotoxic (Bryce et al. 2017); it was, therefore, decided that testing a $23 \mathrm{~h}$ exposure was necessary to confirm whether the $4 \mathrm{~h}$ result was a true positive (Online resource 1). A lower dose range was used for $23 \mathrm{~h}$ compared to $4 \mathrm{~h}$, due to the elongated exposure period resulting in cytotoxicity at the higher doses tested. $\mathrm{MN}$ induction was greater after $4 \mathrm{~h}$, where all concentrations caused significant MN induction and up to fivefold above vehicle control, compared to $23 \mathrm{~h}$, where only one concentration was significant and the number of MN induced lower.

After $23 \mathrm{~h}$, a reduced genotoxic response was noted with only one concentration of cycloheximide, $1.1 \mu \mathrm{M}$, being significant, whereas the higher concentration of $1.4 \mu \mathrm{M}$ was negative. It was noted that the concentration window was particularly narrow, ranging between 0.7 and $1.4 \mu \mathrm{M}$. The 
remaining chemicals, 2,4-DCP, caffeine, phenformin $\mathrm{HCl}$ and QDH, did not significantly increase micronucleus frequency after either $4 \mathrm{~h}$ (data not shown) or $23 \mathrm{~h}$ treatments.

\section{OTA and quercetin increased both p53 and phospho-p53 expression}

Western blotting was used to observe alterations in p53 and phospho-p53 (ser15) expression in response to treatment with the test chemicals, relative to the equivalent vehicle control (Fig. 2). The doses for western blotting and all subsequent endpoints were selected based on the LOEL and/ or reduction in RPD (Fig. 1). A marked increase in p53 accumulation was noted for OTA at $\geq 35 \mu \mathrm{M}$ after $4 \mathrm{~h}$ treatment for both p53 and phospho-p53 expression. The p53 induction was consistent with the positive MN data for OTA (Fig. 1), and indeed the LOEL for p53 and phospho-p53 increases was at a lower concentration than the LOEL for $\mathrm{MN}$ induction $(45 \mu \mathrm{M})$. Oestradiol appeared to increase p53 and phospho-p53 expression at concentrations exceeding $25 \mu \mathrm{M}$, although this was not consistently observed across all replicates. This weaker response perhaps linked into the longer treatment required to induce $\mathrm{MN}$ (Online resource 1).

Of the remaining chemicals, quercetin significantly increased expression for concentrations $\geq 125 \mu \mathrm{M}$ (Online resource 2). Like oestradiol, 2,4-DCP increased p53 expression following $184 \mu \mathrm{M}$ exposure yet this was not observed for all replicates. QDH and the toxic non-carcinogens did not alter p53 or phospho-p53 expression.

\section{Carcinogens produced sizeable gene expression alterations}

The transcription of three genes associated with cancer, CDKN1A, SGK1 and CHKA, were measured using qRTPCR. Fold change results were summarised using a heat map (Fig. 3). The carcinogens OTA and oestradiol significantly altered the expression of CDKNIA mRNA, which encodes p21. Oestradiol significantly increased CDKN1A mRNA expression at doses $\geq 50 \mu \mathrm{M}$, reaching a maximum increase of 17.5 -fold at a concentration of $60 \mu \mathrm{M}$. This is consistent with the previously observed positive p53 response, indicative of a DNA damage response. In contrast to oestradiol, OTA appeared to suppress CDKNIA mRNA expression. OTA produced significant decreases in CDKN1A mRNA expression at all test concentrations, reaching a 7.7-fold decrease at the highest concentration of $45 \mu \mathrm{M}$. A decreasing trend was unexpected, due to OTA causing increased MN, p53 and phospho-p53 levels. The expression of the two remaining genes, $S G K 1$ and $C H K A$, was only altered by OTA. For $S G K 1$, all OTA test concentrations produced a statistically significant decrease in expression, reaching a $>33.3$-fold decrease at $45 \mu \mathrm{M}$. For $C H K A$, a single significant decrease of $35 \mu \mathrm{M}$ was observed for mRNA expression. While toxic non-carcinogen cycloheximide substantially increased gene expression, the data were variable and not significant. Generally, chemicals that altered gene expression also induced micronuclei (Fig. 1).

The only other chemical to alter gene expression was QDH, which reduced expression of CDKNIA by twofold at a single test concentration $(1 \mu \mathrm{M})$. This effect was not dose dependent, as expression did not change significantly at the higher QDH dose of $1.75 \mu \mathrm{M}$. QDH did not, however, alter the related endpoints of $\mathrm{MN}$ or $\mathrm{p} 53$. Other than $\mathrm{QDH}$, none of the misleading in vitro positives and toxic non-carcinogens significantly altered gene expression for the genes tested.

\section{Cell cycle arrest was time-dependent for several test chemicals}

Flow cytometry was used to collect data on alterations in cell cycle dynamics following chemical treatments, to ascertain whether chemicals were capable of inducing cell cycle arrest (Fig. 4).
Fig. 2 The change in expression of p53 and phospho-p53 was determined using western blotting. Representative blots are presented for OTA-treated cell cultures (4 h treatments), where $L$ Ladder of protein standards and $N$-methyl- $N$-nitrosourea (MNU) were used as a positive control. The sizes of protein standard markers are labelled. Doses selected were based on the MN and RPD data generated previously (Fig. 1)
p53
$50 \mathrm{kDa}$
ß-actin
$40 \mathrm{kDa}$

$$
\begin{array}{lllllll}
\text { Ladder } & 0 & 25 & 35 & 40 & 45 \mu \mathrm{M} & \mathrm{MNU}
\end{array}
$$

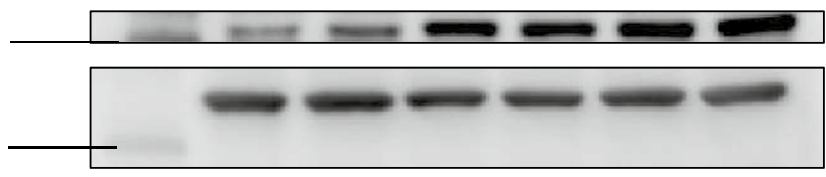

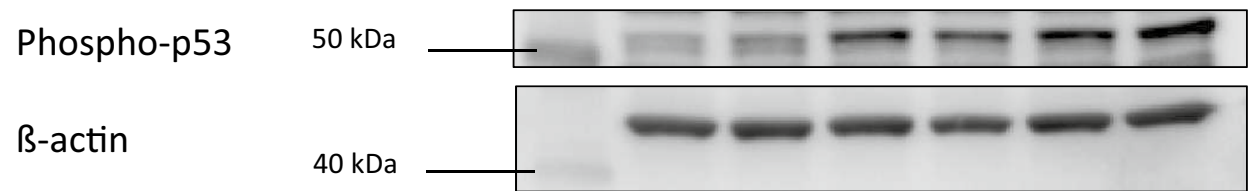




\begin{tabular}{|c|c|c|c|c|c|c|c|c|c|c|}
\hline & \multicolumn{4}{|c|}{ CDKN1A } & \multicolumn{3}{|l|}{ SGK1 } & \multicolumn{3}{|l|}{ CHKA } \\
\hline & Chemical & Conc 1 & Conc 2 & Conc 3 & Conc 1 & Conc 2 & Conc 3 & Conc 1 & Conc 2 & Conc 3 \\
\hline \multirow{2}{*}{ Carcinogens } & OTA & $0.16^{\star \star \star}$ & $0.12^{\star \star \star}$ & $0.13^{* \star *}$ & $0.05^{\star \star \star}$ & $0.03^{* * *}$ & $0.03^{* * *}$ & $0.40^{\star *}$ & 0.63 & 0.7 \\
\hline & Oestradiol & 7.63 * & $17.50^{* * *}$ & $13.02 * * *$ & 0.98 & 1.36 & 1.19 & 1.1 & 1.9 & 1.72 \\
\hline & Quercetin & 2.7 & 2.4 & 2.35 & 1.17 & 0.79 & 0.86 & 1.15 & 1.47 & 1 \\
\hline \multirow[t]{3}{*}{$\begin{array}{l}\text { Misleading in vitro } \\
\text { positives }\end{array}$} & 2,4-DCP & 0.97 & 1.1 & 1.2 & 0.96 & 0.97 & 1.55 & 0.96 & 1.12 & 1.2 \\
\hline & QDH & 0.64 & 0.46 * & 0.86 & 0.64 & 0.46 & 0.86 & 1.15 & 0.67 & 1.14 \\
\hline & Cycloheximide & 1.51 & - & - & 1.2 & 3.61 & 5.31 & 1.81 & 2.04 & 6.79 \\
\hline \multirow[t]{2}{*}{$\begin{array}{l}\text { Toxic non- } \\
\text { carcinogens }\end{array}$} & Caffeine & 1.75 & 1 & 0.31 & 0.97 & 0.67 & 0.26 & 0.98 & 1.26 & 0.29 \\
\hline & Phenformin $\mathrm{HCl}$ & 0.79 & 1.58 & 0.35 & 0.91 & 1.02 & 0.53 & 1.82 & 1.89 & 0.94 \\
\hline
\end{tabular}

\section{Legend}

\begin{tabular}{lrrr} 
& \multicolumn{4}{c}{ Final concentrations $(\mu \mathrm{M})$} \\
Chemical & Conc 1 & Conc 2 & Conc 3 \\
\hline OTA, 4h & 35 & 40 & 45 \\
Oestradiol, 23h & 50 & 60 & 75 \\
\hline Quercetin, 4h & 50 & 125 & 127.5 \\
2,4-DCP, 23h & 61 & 123 & 184 \\
QDH, 23h & 0.5 & 1 & 1.75 \\
\hline Cycloheximide, 4h & 17.8 & 53.3 & 71.1 \\
Caffeine, 23h & 45 & 450 & 770 \\
Phenformin $\mathrm{HCl}, 23 h$ & 0.001 & 0.01 & 0.015
\end{tabular}

Fig. 3 Heat maps summarizing the relative mRNA expression of the CDKN1A, CHKA and SGK1 genes as determined by qRT-PCR $(n=3)$ for $4 \mathrm{~h}$ or $23 \mathrm{~h}$ exposure. Numbers indicate mean fold change relative to the appropriate vehicle control (equal to 1). Individual cells are coloured according to the magnitude of the fold change; shades of

Oestradiol demonstrated a consistent dose-dependent trend towards G1 arrest, with an up to $21 \%$ significant increase in the percentage of cells in G1 phase occurring at 60 and $75 \mu \mathrm{M}$, accompanied by a significant decrease in the proportion of cells in both $\mathrm{S}$ and $\mathrm{G} 2 / \mathrm{M}$ phases. This $\mathrm{G} 1$ cell cycle arrest is consistent with the large increases in CDKNIA mRNA caused by oestradiol (Fig. 3). OTA did not induce any significant cell cycle alterations after $4 \mathrm{~h}$, although did cause a significant decrease in $\mathrm{S}$ phase at $4 \mathrm{~h}$ treatment with a recovery period (Online resource 3 ).

Following a $4 \mathrm{~h}$ exposure, quercetin did not induce significant cell cycle alterations, although a dose-dependent trend was observed (data not shown). To further investigate this apparent effect, and considering quercetin's positive effects for some of the previously described endpoints, the exposure period was extended to $23 \mathrm{~h}$, after which a statistically significant $7 \%$ increase in $\mathrm{G} 2 / \mathrm{M}$ and a $8.7 \%$ decrease in $\mathrm{G} 1$ were observed at $25 \mu \mathrm{M}$, the highest test concentration for this time point. Lower chemical concentrations were used at $23 \mathrm{~h}$ relative to the initial $4 \mathrm{~h}$ studies for quercetin to avoid excessive toxicity. This outcome was consistent with the genotoxicity and p53 increases observed following quercetin exposure (Fig. 1, Online resource 2). green represent a decrease relative to the vehicle control and shades of red represent an increase relative to the vehicle control. Significant results from the statistical analysis (Dunnett's tests) are indicated by $p$ values, where $* p<0.05, * * p<0.01, * * * p<0.001$ (color figure online)

The other misleading in vitro positive compounds QDH and 2,4-DCP did not cause any significant cell cycle alterations following their respective $23 \mathrm{~h}$ exposures. The toxic non-carcinogens cycloheximide and phenformin $\mathrm{HCl}$ did not cause any statistically significant changes, although caffeine did induce a statistically significant decrease in cells in $\mathrm{G} 2 / \mathrm{M}$ at 450 and $700 \mu \mathrm{M}$.

\section{Toxic non-carcinogens altered cell morphology}

The INCell Analyzer 2000-based analyses were used to quantify cell and nuclear area alterations in response to test chemical exposure (Figs. 5, 6). Cells were treated for either $4 \mathrm{~h}$ or $23 \mathrm{~h}$.

For cell and nuclear area, the tested carcinogens and misleading in vitro positive compounds did not produce any significant alterations. Oestradiol induced marked, but non-significant, changes in some cell area categories (Fig. 5). For example, there was a greater than twofold increase in the frequency of cells falling into the 'lowest' area category for all concentrations of oestradiol $(\geq 25 \mu \mathrm{M})(p=0.197$ at $50 \mu \mathrm{M})$. Alongside this change, the frequencies of the largest area categories also decreased. 
Fig. 4 Cell cycle analysis was performed using flow cytometry for samples treated for $4 \mathrm{~h}$ or $23 \mathrm{~h}(n=3)$ to determine whether chemicals altered cell cycle dynamics. Significant results from the statistical analysis (Dunnett's tests) are indicated by $p$ values, where $* p<0.05, * * p<0.01$, $* * * p<0.001$

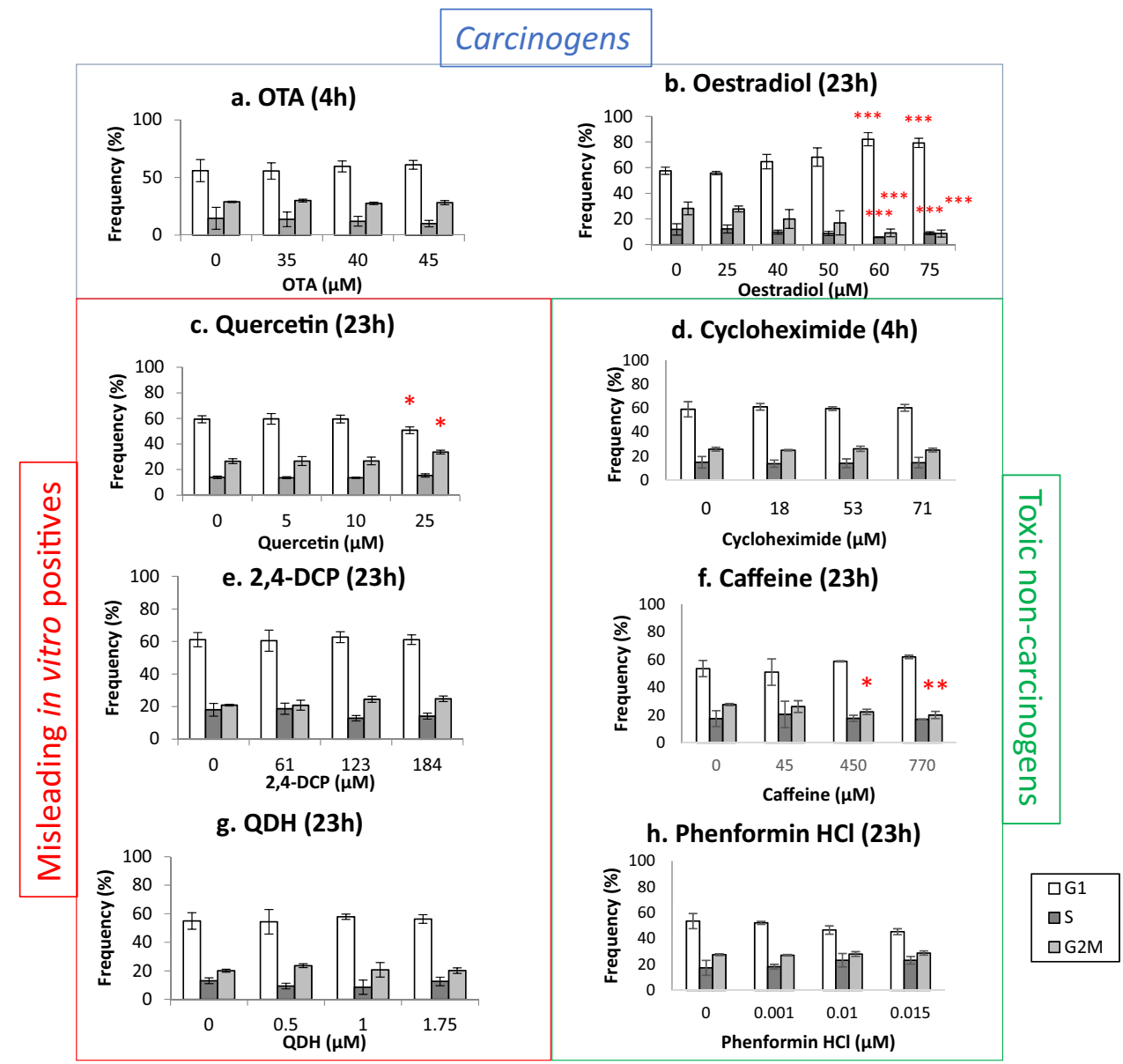

This trend towards smaller cell area is consistent with oestradiol's induction of cell cycle arrest at G1 (Fig. 4), which would produce smaller cells.

The only chemicals to produce significant changes were the toxic non-carcinogens. Caffeine produced statistically significant, dose-dependent decreases in the frequency of cells in the 'highest' size category, from 45 to $770 \mu \mathrm{M}$, and increased the frequency of cells in the 'lowest' category at $770 \mu \mathrm{M}$ only (Fig. 5). These results suggest that caffeine reduced cell area. Cell area was also altered by cycloheximide and phenformin $\mathrm{HCl}$, although statistically significant effects were observed only at lower concentrations and did not appear to be dose dependent.

For nuclear area, only cycloheximide and caffeine caused significant changes (Fig. 6). Cycloheximide reduced the proportion of the smallest, or 'lowest', nuclear area category for the lowest test concentration, $18 \mu \mathrm{M}$, only. Higher concentrations, however, did not cause statistically significant changes. Caffeine significantly changed the proportion of cells in the 'normal' and 'highest' categories following treatment after the highest treatment concentration of $770 \mu \mathrm{M}$, although there was not a clear result in terms of the direction of change of nuclear morphology. Overall, cell area appeared to be more sensitive for the detection of morphological changes caused by test chemicals than nuclear area.

\section{Mitochondrial activity was mostly unchanged}

Bioenergetics analysis was completed using the Seahorse Bioanalyzer, to allow effects on mitochondrial respiration to be observed (Fig. 7). The two carcinogens did not cause any statistically significant changes for this endpoint; the sole chemical to produce a statistically significant alteration from the control was 2,4-DCP, producing a $20 \%$ reduction in mitochondrial activity after $23 \mathrm{~h}$ at the 50\% RPD concentration of $184 \mu \mathrm{M}$. The data for several other chemical treatments indicated a similar decreasing trend in OCR/ECAR fold change with increasing test chemical concentration, although these alterations were not found to be statistically significant.

\section{ToxPi GUI indicated carcinogens' greater potency}

To visually summarise the results of the multiple-endpoint approach, the ToxPi GUI software was used to generate diagrammatical representations for all of the chemicals 
Fig. 5 Cell area changes from data obtained via the INCell Analyzer 2000 followed by Matlab-based image analysis. The frequency of cells (\%) in each quintile category is plotted. Significant results from the statistical analysis (Dunnett's tests) are indicated by $p$ values, where $* p<0.05, * * p<0.01$, $* * * p<0.001$

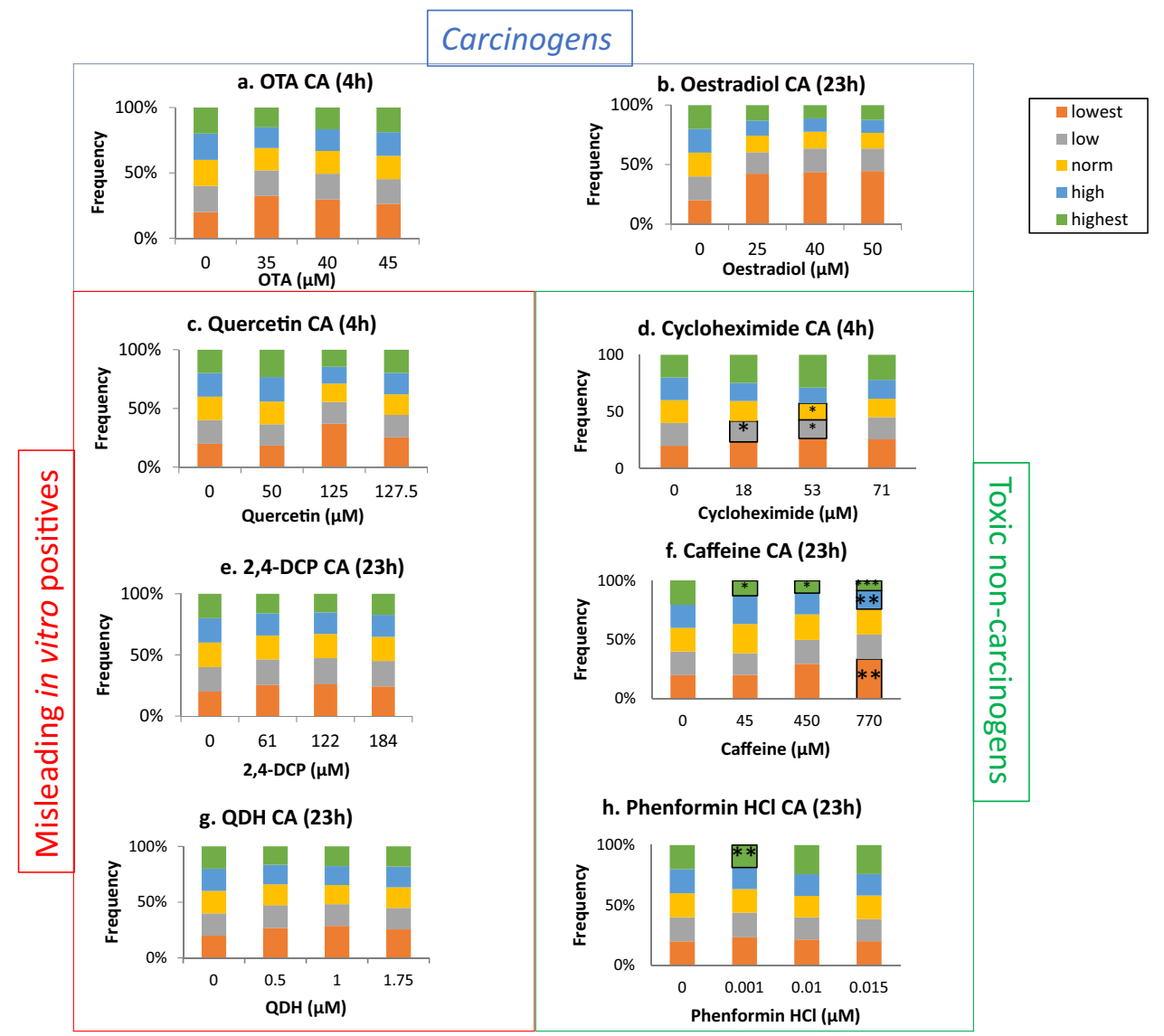

(Fig. 8a). Integrated Signature of Carcinogenicity (ISC) scores (Wilde et al. 2018) were also generated to quantitatively rank the chemicals based on their collective effects at the highest tested concentration that also did not exceed a 50\% reduction in RPD (Fig. 1). The ISC scores were calculated based on the sum of the mean fold changes for the different endpoints, with endpoints weighted, as appropriate.

ISC scores demonstrated that carcinogens OTA and oestradiol were the highest ranking of the eight test chemicals, with OTA ranking first and oestradiol, second. The remaining test chemicals, cycloheximide, quercetin, caffeine, 2,4-DCP, phenformin $\mathrm{HCl}$ and $\mathrm{QDH}$, ranked lower. These ISC scores were combined with ISC scores from the aforementioned publication by Wilde et al., where eight genotoxic and non-genotoxic carcinogens were studied (Fig. 8b). It was observed that carcinogens generally ranked higher than misleading in vitro positives and toxic non-carcinogens, with the exception of cycloheximide.

\section{Discussion}

Improved in vitro genotoxicity tests are essential for the accurate prediction of the carcinogenic potential of chemicals in vivo and the avoidance of unnecessary animal tests.
The present study aimed to evaluate a more sophisticated, multiple-endpoint in vitro approach for distinguishing between selected carcinogens, misleading in vitro positive compounds and toxic non-carcinogens, as compared to in vivo carcinogenicity outcomes where relevant.

\section{Outcomes for multiple endpoints in vitro indicated carcinogens' mechanisms}

The two tested carcinogens' endpoint outcomes generally reflected their established mechanisms of carcinogenesis. First, the carcinogen OTA induced MN (Fig. 1), supporting a genotoxic mode of carcinogenesis for this agent (Table 1). OTA also increased p53 and phospho-p53 expression (Fig. 2) and altered gene expression (Fig. 3), which supported the $\mathrm{MN}$ results. It was noted that while $\mathrm{MN}$ frequency increased only at the highest concentration tested $(45 \mu \mathrm{M})$, p53 and phospho-p53 were increased at doses below the lowest observed effect level for MN (Fig. 1). Equally, oestradiol elicited significant effects for non-MN endpoints after $23 \mathrm{~h}$ exposure, while only inducing $\mathrm{MN}$ after $48 \mathrm{~h}$. This important observation demonstrated that other endpoints exhibited greater sensitivity than MN frequency and perhaps indicates the role of DNA repair at lower concentrations preventing eventual MN formation (Zair et al. 2011). The 
Fig. 6 Nuclear area changes from data obtained via the INCell Analyzer 2000 followed by Matlab-based image analysis. The frequency of cells (\%) in each quintile category is plotted $(n=3)$. Significant results from the statistical analysis (Dunnett's tests) are indicated by $p$ values, where $* p<0.05$, $* * p<0.01$, *** $p<0.001$

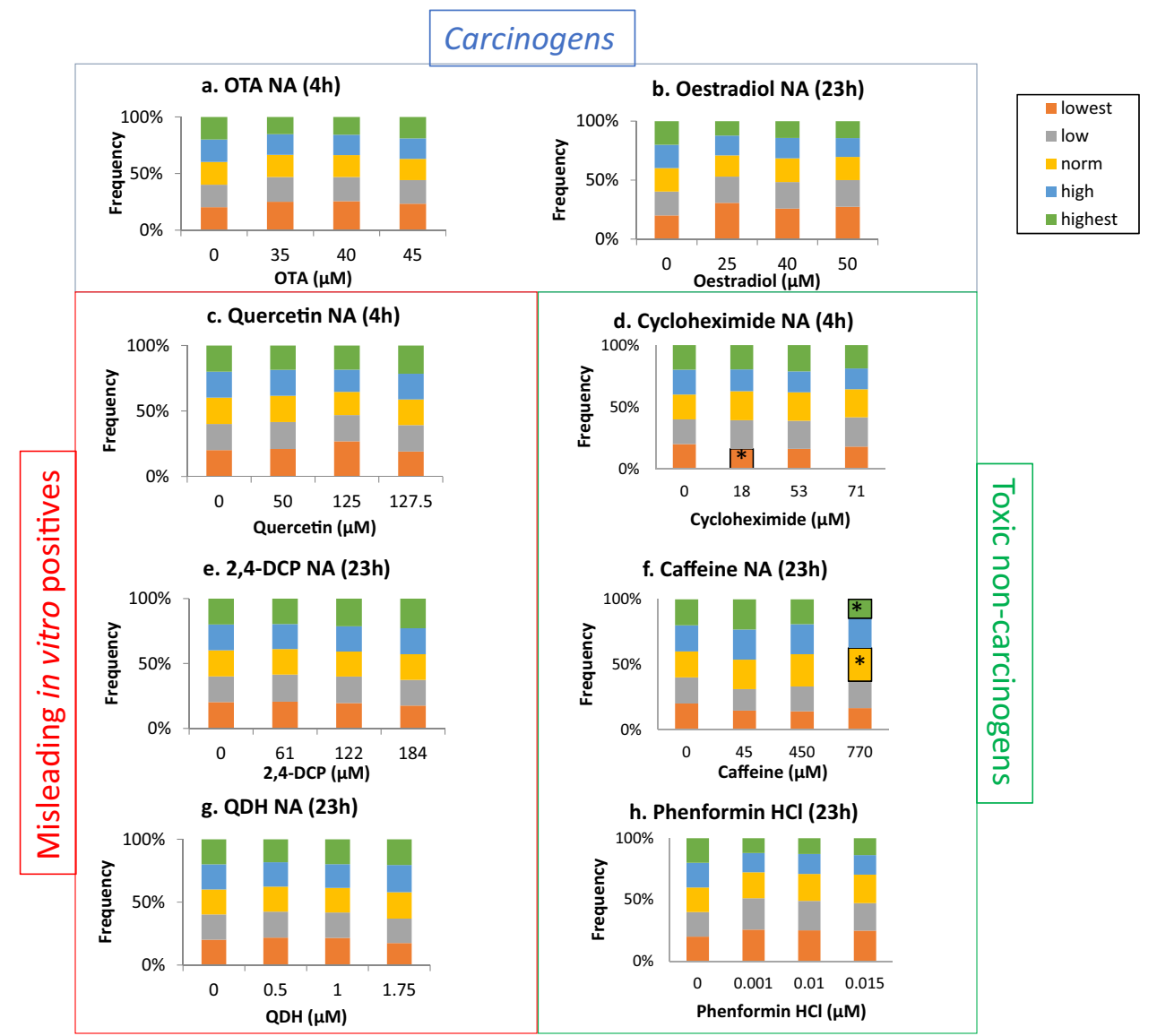

decreased expression of CDKN1A mRNA caused by OTA was unexpected, when it was considered that OTA increased the related endpoints of MN frequency and p53 expression. A similar phenomenon of p53 up-regulation accompanied by $\mathrm{p} 21$ inhibition has, however, been observed previously following OTA exposure and was hypothesised to be due to p53-independent inhibitory action of OTA on transcription (Golli Bennour et al. 2009). Indeed, decreased p21 is associated with a cancer phenotype (Gartel and Radhakrishnan 2005). OTA's effects on the cell cycle were minimal, which supported the reduced p21 expression; such effects were also time-dependent, with $4 \mathrm{~h}$ treatment producing negative results (Fig. 4), whereas recovery led to reduced $\mathrm{S}$ phase frequency (Online resource 2).

Oestradiol, like OTA, was genotoxic yet was only positive after an elongated treatment period of $48 \mathrm{~h}$ (Fig. 1, Online resource 1). As for OTA, this indicates that exposure duration can be important for observing positive effects. While oestradiol was negative for MN after $23 \mathrm{~h}$, this timepoint produced sizeable changes in other endpoints; for example, a large increase in $C D K N 1 A$ mRNA accompanied by cell cycle arrest at $\mathrm{G} 1$ at concentrations $\geq 50 \mu \mathrm{M}$ were observed. Oestradiol's effects on the cell cycle have been documented previously (Yue et al. 2013). It could, however, be argued that $\mathrm{G} 1$ arrest would not be consistent with mismatch repair of associated replication errors (Yue et al. 2013), which is more likely to occur during G2 arrest (Hawn et al. 1995), implying alternative mechanisms were at work.

The two carcinogens did not alter cellular and nuclear morphology endpoints (Figs. 5, 6) and this contrasted with positive results for most carcinogens in Wilde et al. (2018). This might owe to the carcinogens selected here having different mechanisms and potency to those tested previously.

Overall, the carcinogens produced clear, dose-dependent and in some cases time-dependent responses for several endpoints, further supporting the use of integrated, multipleendpoint testing approaches for recognising carcinogens.

\section{Misleading in vitro positive compounds and toxic non-carcinogens produced largely negative results}

Following validation of the approach with carcinogens, it was essential to establish whether the non-carcinogens produced different results and did not erroneously test positive. To evaluate this, three misleading in vitro positive compounds and three toxic non-carcinogens were used.

Of the three misleading positives, quercetin elicited the greatest effect, inducing MN (Fig. 1), p53, phospho-p53 (Fig. 2) after $4 \mathrm{~h}$ treatments and G2/M arrest after $23 \mathrm{~h}$ (Fig. 4). The overall outcomes for quercetin suggested 


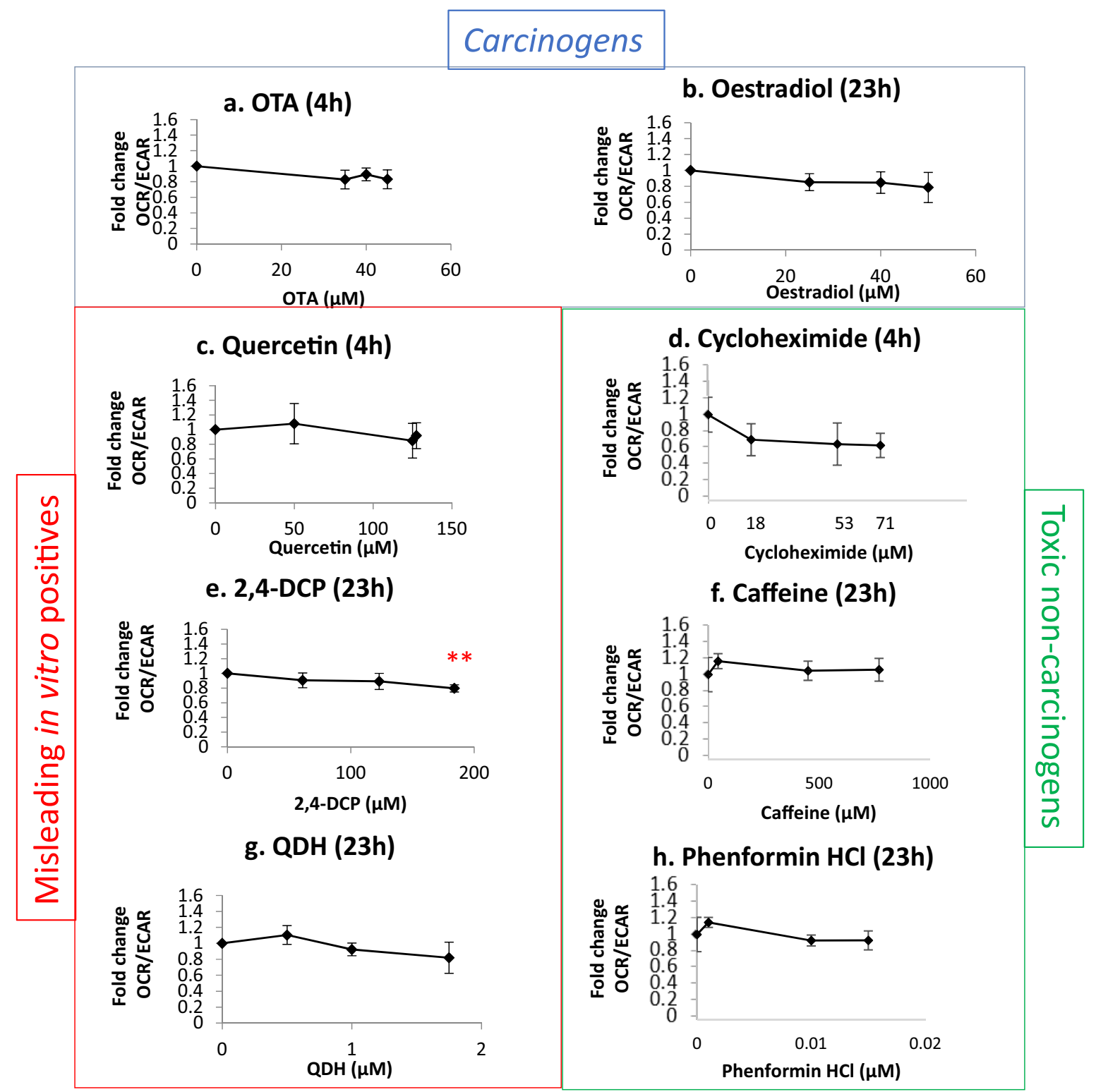

Fig. 7 Bioenergetics analysis of control and treated cells using the Seahorse $\mathrm{XF}^{\mathrm{e}} 24$ Bioanalyzer $(n \geq 3)$ to establish whether chemicals induced a mitochondrial stress phenotype. The fold change for the ratio of oxygen consumption rate (OCR) and extracellular acidifica- tion rate (ECAR) is plotted against chemical concentration. Significant results from the statistical analysis (Dunnett's tests) are indicated by $p$ values, where $* p<0.05, * * p<0.01$, *** $p<0.001$ behaviour reminiscent of genotoxic carcinogens, such as OTA, as well as other compounds in this category (Wilde et al. 2018). Overall, these data imply that quercetin is fundamentally genotoxic under these conditions, which in vitro, has been attributed to auto-oxidation effects (Harwood et al. 2007). This provides cause to question whether classification of chemicals into discrete categories is an oversimplification (Wilde et al. 2018), and quercetin is a carcinogen, particularly as it has a $\mathrm{TD}_{50}$ value (Table 2).

In contrast, other misleading positive compounds, 2,4-DCP and QDH, produced a very limited number of positive results in a sporadic manner. QDH altered CDKN1A expression at $1 \mu \mathrm{M}$, yet not at the highest dose of $1.75 \mu \mathrm{M}$, suggesting that this effect was not dose dependent. Similarly, 2,4-DCP appeared to alter p53 levels, yet not phospho-p53, and the result was not consistent across experimental replicates. Inconsistency within 2,4-DCP test results has been reported previously (Fowler et al. 2012a). As 2,4-DCP did not increase MN frequency, the p53 result may have been an artefact of toxicity. The only endpoint that 2,4-DCP significantly altered was mitochondrial activity, being the only chemical to affect this endpoint (Fig. 7). 


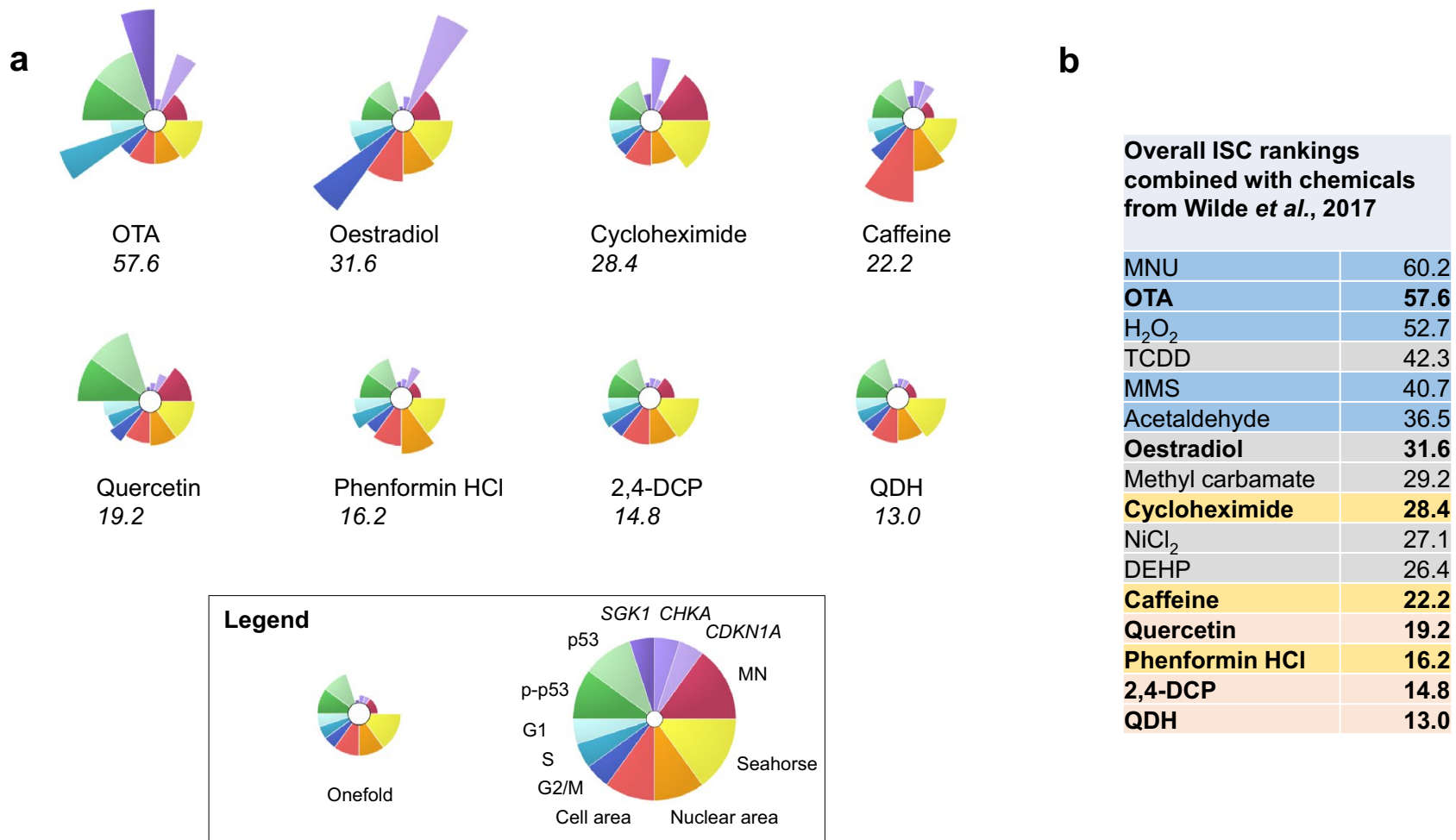

Fig. 8 a Outputs from the Toxicological Prioritization Index (ToxPi) GUI summarising the fold changes for the endpoints at the $50 \%$ RPD-inducing concentration. Chemicals were ranked according to their Integrated Signature of Carcinogenicity scores, from highest to lowest. Fold changes were square-rooted and values $<$ onefold were inverted to give values $>$ onefold. b Table summarising ISCs for all

A possible explanation is 2,4-DCP's proposed involvement in in vitro superoxide radical generation (Garg et al. 2001). Interestingly, while QDH appeared almost inert, only inducing one positive outcome, it was also the most potent apart from phenformin $\mathrm{HCl}$, eliciting a $50 \%$ reduction in RPD at lower molarity than most other chemicals (i.e., $\leq 1.75 \mu \mathrm{M}$ ).

Similar to the misleading positive chemicals, the toxic non-carcinogens cycloheximide, caffeine and phenformin $\mathrm{HCl}$ were also found to produce largely negative results. Cycloheximide had the largest effect, inducing MN at two different timepoints (Fig. 1, Online resource 1) and altering cell and nuclear area (Figs. 5, 6); however, these were not usually dose-dependent patterns, with sometimes only one, low test concentration producing a significant result. Despite being considered a non-carcinogen, previous studies have also demonstrated that cycloheximide can induce genotoxicity, including MN, in both in vitro and in vivo models (Seiichi et al. 1990; Bašić-Zaninović et al. 1991). Cycloheximide was shown to induce $\mathrm{MN}$ via both clastogenicity and aneugenicity (Basic-Zaninovic et al. 1987). Collectively, these results suggest that cycloheximide is a genotoxicant with chemicals tested using the multiple-endpoint method, including those from Wilde et al. (2018) (non-emboldened text). Chemicals in bold are from the current publication. Blue = genotoxic carcinogens; grey $=$ non-genotoxic carcinogens; yellow $=$ toxic non-carcinogens; pink $=$ misleading in vitro positives (color figure online)

carcinogenic potential; therefore, its classification as a noncarcinogen might not be accurate.

Caffeine produced positive results for three endpoints, with some dose-dependent effects. Caffeine reduced G2M frequency (Fig. 4) and reduced cell and possibly nuclear area (Figs. 5, 6), supporting cell cycle arrest in G1 phase. In support of such effects, caffeine has been demonstrated to induce TP53-independent G1 arrest in human cells (Qi et al. 2002), which supports this chemical's negative western blot data. The positive results for caffeine could relate to toxic rather than carcinogen effects. Phenformin $\mathrm{HCl}$, however, tested negative for all endpoints with the exception of a positive result for one quintile for cell area, although this was not dose dependent. Despite negative outcomes, it was the most potent agent given that the highest dose tested was $0.1 \mu \mathrm{M}$; this was a far lower molarity than that of other compounds.

Overall, these results indicate that while misleading in vitro positive chemicals and toxic non-carcinogens did produce a small number of positive results, these were generally not inter-supporting, not across multiple doses and of a smaller magnitude than for carcinogens. Compared to the carcinogens, therefore, overall effects for non-carcinogens 
were noticeably weaker within this test system. It is perhaps worth considering that a minimum 'threshold' number of concentrations or endpoints need to be significantly altered for a chemical to be classed as a 'carcinogen'.

\section{ISC scores successfully distinguished carcinogens from non-carcinogens}

ToxPi GUI analysis and ISC score generation enabled the observation of overall potency of the test chemicals based on all endpoints at the greatest test concentration (Fig. 8); the two carcinogens, OTA and oestradiol, produced the two highest ISC scores, with OTA ranking first (57.6) and oestradiol, second (31.6). This order also reflected the $\mathrm{TD}_{50}$ rank order in Table 2, with OTA's lower $\mathrm{TD}_{50}$ indicating greater potency relative to oestradiol. The higher ranking of the genotoxic carcinogen, OTA, relative to non-genotoxic, or less potently genotoxic, carcinogen, oestradiol, was consistent with the results for these two carcinogen subtypes published previously (Wilde et al. 2018).

Other chemicals ranked below the two carcinogens in terms of ISC score (Fig. 8). While there was some overlap between toxic non-carcinogens and misleading positives, toxic non-carcinogens generally ranked higher with an average ISC of 22.3, compared to 15.7 for misleading positives. There did appear to be some overlap between non-carcinogen ISCs and non-genotoxic carcinogens ISCs published previously by Wilde et al. (2018); non-carcinogen cycloheximide's ISC was 28.4, whereas non-genotoxic carcinogens $\mathrm{NiCl}_{2}$ and DEHP produced lower ISCs of 27.1 and 26.4 , respectively. As previously mentioned, it is, however, possible that cycloheximide is inherently genotoxic (Fig. 1, Online resource 1) and so classification as a non-carcinogen might not fully reflect its biological activity. This is supported by the fact the second highest non-carcinogen ISC was 22.2, which was less than any carcinogen, genotoxic or non-genotoxic, tested. This suggests that the multiple-endpoint approach is less likely than single endpoint approaches to generate misleading positive results and may be superior for recognising carcinogenic potential and identifying such mechanisms of action. However, given that cycloheximide's score exceeded that of two non-genotoxic carcinogens, further validation of the approach and perhaps the addition of other endpoints may be appropriate in future work.

The greater ISCs for carcinogens compared to non-carcinogens implied that carcinogens produced a greater biological effect for endpoints relating to the Hallmarks of Cancer (Hanahan and Weinberg 2011), supporting the use of such a test to identify chemicals' carcinogenic potential. It was noted that multiple endpoints altered by carcinogens tended to be mechanistically inter-supporting. Changes were also often observed for at least two individual doses, occurring in a dose-dependent manner. Non-significant changes also contributed towards the overall ISC score, meaning that more subtle effects could assist in informing chemical risk assessment. These outcomes all support the use of an integrated and quantitative weight of evidence (WoE) approach for distinguishing between carcinogens and non-carcinogens in vitro, rather than isolated, single mode of action endpoints and tiered approaches (Rovida et al. 2015; Thybaud et al. 2007). Further study will assist in determining which endpoints are most powerful for distinguishing between carcinogens and non-carcinogens; the data from Wilde et al. (2018) and the present study suggest that $\mathrm{MN}$, p53, CDKN1A and cell cycle data may be among the most powerful.

\section{Conclusions}

In vitro genotoxicity tests remain rudimentary and often fail to successfully distinguish carcinogens from non-carcinogens. In the first study of its kind, we have provided compelling evidence for a human cell-based, multiple-endpoint in vitro carcinogenicity test distinguishing between carcinogens and non-carcinogens. This holistic approach also identifies mechanisms of carcinogenic action in vitro, while identifying results that are not dose dependent. With further validation, it is hoped that the ranking of chemicals based on their ISC scores may allow a minimum 'cut-off' score for carcinogens to be established. This could support the avoidance of misclassifying non-carcinogens as carcinogens via in vitro test results. Indeed, we have demonstrated that there is potential for applying holistic approaches to in vitro 3D cell culture models in future (Chapman et al. 2014; Shah et al. 2018). Overall, holistic approaches appear to be a valuable tool for identifying non-carcinogens at the in vitro stage, avoiding unnecessary in vivo testing.

Acknowledgements The authors thank Margaret Clatworthy, Sally James (Swansea University), Dr. Val Millar and Angela Davies (both GE Healthcare) for their technical assistance. The authors also thank Professor David Kirkland for his advice on compound selection. We also thank the journal reviewer for their helpful comments.

Author contributions KEC wrote the manuscript and performed the majority of the experimental work and data analysis. ECW, FMC, JRV, UKS and LMS contributed to the experimental work and data analysis. ALS contributed to analysis tool development and writing of the manuscript. MRB and JT aided with the development of analysis tools. ATD co-supervised LMS's PhD studentship. GEJ and SHD contributed to study design and writing of the manuscript. GJSJ led the study design, secured the funding, and contributed to the manuscript.

Funding This work was supported by the National Centre for the Replacement, Refinement and Reduction (3Rs) of Animals in Research (NC3Rs) (Grant number NC/K500033/1 to GJSJ).

Data availability Will be made available. 
Code availability Will be made available.

\section{Compliance with ethical standards}

Conflict of interest The authors declare that they have no conflict of interest.

Ethics approval Not applicable.

Consent to participate Not applicable.

Consent for publication Not applicable.

Open Access This article is licensed under a Creative Commons Attribution 4.0 International License, which permits use, sharing, adaptation, distribution and reproduction in any medium or format, as long as you give appropriate credit to the original author(s) and the source, provide a link to the Creative Commons licence, and indicate if changes were made. The images or other third party material in this article are included in the article's Creative Commons licence, unless indicated otherwise in a credit line to the material. If material is not included in the article's Creative Commons licence and your intended use is not permitted by statutory regulation or exceeds the permitted use, you will need to obtain permission directly from the copyright holder. To view a copy of this licence, visit http://creativecommons.org/licenses/by/4.0/.

\section{References}

Adeleye Y, Andersen M, Clewell R, Davies M, Dent M, Edwards S, Fowler P, Malcomber S, Nicol B, Scott A (2015) Implementing Toxicity Testing in the 21st Century (TT21C): Making safety decisions using toxicity pathways, and progress in a prototype risk assessment. Toxicology 332:102-111

Basic-Zaninovic T, Matijasevic Z, Alacevic M (1987) The relative size of micronuclei as an indicator of the mechanism of micronuclei induction by cycloheximide. Prehrambeno-tehnoloska i biotehnoloska revija (Yugoslavia) 25(3):69-72

Bašić-Zaninović T, Papeš D, Franekić J (1991) Cycloheximide genotoxicity in in vitro and in vivo test systems. Mut Res Lett 263(4):203-210

Benigni R (2014) Predicting the carcinogenicity of chemicals with alternative approaches: recent advances. Expert Opin Drug Metab Toxicol 10(9):1199-1208

Boorman, G. (1989). NTP Technical report on the toxicology and carcinogenesis studies of ochratoxin A (CAS No. 303-47-9) in F344/N Rats (Gavage Studies)(NIH Publication No. 89-2813). National Toxicology Program, US Department of Health and Human Services: Research Triangle Park, NC

Bourcier T, McGovern T, Stavitskaya L, Kruhlak N, Jacobson-Kram D (2015) Improving prediction of carcinogenicity to reduce, refine, and replace the use of experimental animals. J Am Assoc Lab Anim Sci 54(2):163-169

Breheny D, Oke O, Faux SP (2011) The use of in vitro systems to assess cancer mechanisms and the carcinogenic potential of chemicals. Alternat Lab Anim-ATLA 39(3):233

Brusehafer K, Rees BJ, Manshian BB, Doherty AT, O'Donovan MR, Doak SH, Jenkins GJ (2014) Chromosome breakage induced by the genotoxic agents mitomycin $\mathrm{C}$ and cytosine arabinoside is concentration and p53 dependent. Toxicol Sci 140(1):94-102. https://doi.org/10.1093/toxsci/kfu058
Bryce SM, Bernacki DT, Bemis JC, Spellman RA, Engel ME, Schuler M, Lorge E, Heikkinen PT, Hemmann U, Thybaud V (2017) Interlaboratory evaluation of a multiplexed high information content in vitro genotoxicity assay. Environ Mol Mutagen 58(3):146-161

Bukowska B (2003) Effects of 2, 4-D and its metabolite 2, 4-dichlorophenol on antioxidant enzymes and level of glutathione in human erythrocytes. Comp Biochem Physiol C 135(4):435-441

Burden N, Chapman K, Sewell F, Robinson V (2015) Pioneering better science through the 3Rs: an introduction to the national centre for the replacement, refinement, and reduction of animals in research (NC3Rs). J Am Assoc Lab Anim Sci 54(2):198-208

Casella ML, Parody JP, Ceballos MP, Quiroga AD, Ronco MT, Francés DE, Monti JA, Pisani GB, Carnovale CE, Carrillo MC (2014) Quercetin prevents liver carcinogenesis by inducing cell cycle arrest, decreasing cell proliferation and enhancing apoptosis. Mol Nutr Food Res 58(2):289-300

Chapman F (2018) Development of a passive dosing system for exposure with hydrophobic compounds in in vitro genotoxicity tests. Swansea University Medical School, issuing body.

Chapman KE, Thomas AD, Wills JW, Pfuhler S, Doak SH, Jenkins GJ (2014) Automation and validation of micronucleus detection in the 3D EpiDerm ${ }^{\mathrm{TM}}$ human reconstructed skin assay and correlation with 2D dose responses. Mutagenesis 29(3):165-175

Chapman KE, Doak SH, Jenkins GJ (2015) Acute dosing and p53-deficiency promote cellular sensitivity to DNA methylating agents. Toxicol Sci 144(2):357-365

Chapman FM, Sparham C, Hastie C, Sanders DJ, van Egmond R, Chapman KE et al (2020) Comparison of passive-dosed and solvent spiked exposures of pro-carcinogen, benzo [a] pyrene, to human lymphoblastoid cell line, MCL-5. Toxicol Vitro 67:104905

Cierniak A, Papiez M, Kapiszewska M (2003) Modulatory effect of quercetin on DNA damage, induced by etoposide in bone marrow cells and on changes in the activity of antioxidant enzymes in rats. Rocz Akad Med Bialymst 1995(49):167-169

Clarke JJ, Sokal DC, Cancel AM, Campen DB, Gudi R, Wagner VO, San RH, Jacobson-Kram D (2001) Re-evaluation of the mutagenic potential of quinacrine dihydrochloride dihydrate. Mutat Res/Genetic Toxicol Environ Mutagen 494(1):41-53

Council NR (2007) Toxicity testing in the 21st century: a vision and a strategy. National Academies Press, Washington

Dai J, Wright MW, Manderville RA (2003) Ochratoxin A forms a carbon-bonded C8-deoxyguanosine nucleoside adduct: implications for C8 reactivity by a phenolic radical. J Am Chem Soc 125(13):3716-3717

El Adlouni C, Pinelli E, Azemar B, Zaoui D, Beaune P, Pfohl-Leszkowicz A (2000) Phenobarbital increases DNA adduct and metabolites formed by ochratoxin A: role of CYP 2C9 and microsomal glutathione- $S$-transferase. Environ Mol Mutagen 35(2):123-131

Fenech M, Chang WP, Kirsch-Volders M, Holland N, Bonassi S, Zeiger E (2003) HUMN project: detailed description of the scoring criteria for the cytokinesis-block micronucleus assay using isolated human lymphocyte cultures. Mutat Res 534(1-2):65-75

Fowler P, Smith K, Young J, Jeffrey L, Kirkland D, Pfuhler S, Carmichael P (2012a) Reduction of misleading ("false") positive results in mammalian cell genotoxicity assays. I. Choice of cell type. Mutat Res 742(1):11-25

Fowler P, Smith K, Young J, Jeffrey L, Kirkland D, Pfuhler S, Carmichael P (2012b) Reduction of misleading ("false") positive results in mammalian cell genotoxicity assays. I. Choice of cell type. Mutat Res 742(1-2):11-25

Fowler P, Smith R, Smith K, Young J, Jeffrey L, Carmichael P, Kirkland D, Pfuhler S (2014) Reduction of misleading ("false") positive results in mammalian cell genotoxicity assays. III: sensitivity of human cell types to known genotoxic agents. Mutat Res 767:28-36 
Garg R, Kapur S, Hansch C (2001) Radical toxicity of phenols: a reference point for obtaining perspective in the formulation of QSAR. Med Res Rev 21(1):73-82

Gartel AL, Radhakrishnan SK (2005) Lost in transcription: p21 repression, mechanisms, and consequences. Cancer Res 65(10):3980-3985

Golli Bennour EE, Rodriguez-Enfedaque A, Bouaziz C, Ladjimi M, Renaud F, Bacha H (2009) Toxicities induced in cultured human hepatocarcinoma cells exposed to ochratoxin A: oxidative stress and apoptosis status. J Biochem Mol Toxicol 23(2):87-96

González-Arias CA, Benitez-Trinidad AB, Sordo M, Robledo-Marenco L, Medina-Díaz IM, Barrón-Vivanco BS, Marín S, Sanchis V, Ramos AJ, Rojas-García AE (2014) Low doses of ochratoxin A induce micronucleus formation and delay DNA repair in human lymphocytes. Food Chem Toxicol 74:249-254

Hanahan D, Weinberg RA (2011) Hallmarks of cancer: the next generation. Cell 144(5):646-674

Harwood M, Danielewska-Nikiel B, Borzelleca JF, Flamm GW, Williams GM, Lines TC (2007) A critical review of the data related to the safety of quercetin and lack of evidence of in vivo toxicity, including lack of genotoxic/carcinogenic properties. Food Chem Toxicol 45(11):2179-2205

Hawn MT, Umar A, Carethers JM, Marra G, Kunkel TA, Boland CR, Koi M (1995) Evidence for a connection between the mismatch repair system and the $\mathrm{G} 2$ cell cycle checkpoint. Cancer Res 55(17):3721-3725

Hernández LG, van Steeg H, Luijten M, van Benthem J (2009) Mechanisms of non-genotoxic carcinogens and importance of a weight of evidence approach. Mutat Res 682(2):94-109

Hernández LG, van Benthem J, Johnson GE (2013) A mode-of-action approach for the identification of genotoxic carcinogens. PLoS ONE 8(5):e64532

Heussner AH, Bingle LE (2015) Comparative ochratoxin toxicity: a review of the available data. Toxins (Basel) 7(10):4253-4282

Kirkland D (2010) Evaluation of different cytotoxic and cytostatic measures for the in vitro micronucleus test (MNVit): summary of results in the collaborative trial. Mutat Res 702(2):139-147

Kirkland D, Henderson L, Marzin D, Müller L, Parry J, Speit G, Tweats D, Williams G (2005a) Testing strategies in mutagenicity and genetic toxicology: an appraisal of the guidelines of the European Scientific Committee for Cosmetics and Non-Food Products for the evaluation of hair dyes. Mutat Res 588(2):88-105

Kirkland D, Aardema M, Henderson L, Müller L (2005b) Evaluation of the ability of a battery of three in vitro genotoxicity tests to discriminate rodent carcinogens and non-carcinogens: I. Sensitivity, specificity and relative predictivity. Mutat Res 584(1-2):1-256

Kirkland D, Aardema M, Müller L, Hayashi M (2006) Evaluation of the ability of a battery of three in vitro genotoxicity tests to discriminate rodent carcinogens and non-carcinogens: II. Further analysis of mammalian cell results, relative predictivity and tumour profiles. Mutat Res 608(1):29-42

Kirkland D, Pfuhler S, Tweats D, Aardema M, Corvi R, Darroudi F, Elhajouji A, Glatt H, Hastwell P, Hayashi M, Kasper P, Kirchner S, Lynch A, Marzin D, Maurici D, Meunier J-R, Müller L, Nohynek G, Parry J, Parry E, Thybaud V, Tice R, van Benthem J, Vanparys P, White P (2007) How to reduce false positive results when undertaking in vitro genotoxicity testing and thus avoid unnecessary follow-up animal tests: Report of an ECVAM Workshop. Mutat Res 628(1):31-55. https://doi.org/10.1016/j.mrgen tox.2006.11.008

Kirkland D, Kasper P, Müller L, Corvi R, Speit G (2008) Recommended lists of genotoxic and non-genotoxic chemicals for assessment of the performance of new or improved genotoxicity tests: a follow-up to an ECVAM workshop. Mutat Res 653(1):99-108

Kirkland D, Kasper P, Martus HJ, Müller L, van Benthem J, Madia F, Corvi R (2016) Updated recommended lists of genotoxic and non-genotoxic chemicals for assessment of the performance of new or improved genotoxicity tests. Mutat Res 795:7-30

McKim J, James M (2010) Building a tiered approach to in vitro predictive toxicity screening: a focus on assays with in vivo relevance. Comb Chem High Throughput Screen 13(2):188-206

Munro IC, Carlo GL, Orr JC, Sund KG, Wilson RM, Kennepohl E, Lynch BS, Jablinske M (1992) A comprehensive, integrated review and evaluation of the scientific evidence relating to the safety of the herbicide 2, 4-D. J Am Coll Toxicol 11(5):559-664

Pamukcu AM, Yalçiner Ş, Hatcher JF, Bryan GT (1980) Quercetin, a rat intestinal and bladder carcinogen present in bracken fern (Pteridium aquilinum). Cancer Res 40(10):3468-3472

Pfohl-Leszkowicz A, Castegnaro M (2005) Further arguments in favour of direct covalent binding of Ochratoxin A (OTA) after metabolic biotransformation. Food Addit Contam 22(s1):75-87

Pfuhler S, Kirkland D, Kasper P, Hayashi M, Vanparys P, Carmichael P, Dertinger S, Eastmond D, Elhajouji A, Krul C (2009) Reduction of use of animals in regulatory genotoxicity testing: identification and implementation opportunities-report from an ECVAM workshop. Mutat Res 680(1):31-42

Pfuhler S, Fellows M, Van Benthem J, Corvi R, Curren R, Dearfield K, Fowler P, Frötschl R, Elhajouji A, Le Hégarat L (2011) In vitro genotoxicity test approaches with better predictivity: summary of an IWGT workshop. Mutat Res 723(2):101-107

Program NT (1992) Toxicology and carcinogenesis studies of Quercetin (CAS No. 117-39-5) in F344 rats (feed studies). Natl Toxicol Program Tech Rep Ser 409:1

Qi W, Qiao D, Martinez JD (2002) Caffeine induces TP53-independent G1-phase arrest and apoptosis in human lung tumor cells in a dose-dependent manner. Radiat Res 157(2):166-174

Reif DM, Sypa M, Lock EF, Wright FA, Wilson A, Cathey T, Judson RR, Rusyn I (2013) ToxPi GUI: an interactive visualization tool for transparent integration of data from diverse sources of evidence. Bioinformatics 29(3):402-403

Rovida C, Alépée N, Api AM, Basketter DA, Bois FY, Caloni F, Corsini E, Daneshian M, Eskes C, Ezendam J (2015) Integrated Testing Strategies (ITS) for safety assessment. ALTEX-Alternat Anim Experiment 32(1):25-40

Seager AL, Shah UK, Brusehafer K, Wills J, Manshian B, Chapman KE, Thomas AD, Scott AD, Doherty AT, Doak SH, Johnson GE, Jenkins GJ (2014) Recommendations, evaluation and validation of a semi-automated, fluorescent-based scoring protocol for micronucleus testing in human cells. Mutagenesis 29(3):155-164. https ://doi.org/10.1093/mutage/geu008

Sei-ichi S, Haruo T, Naomichi I (1990) A comparison of micronucleus induction in 3 mouse strains with representative clastogens. Toxicol Lett 52(2):215-220

Shah UK, Seager AL, Fowler P, Doak SH, Johnson GE, Scott SJ et al (2016) A comparison of the genotoxicity of benzo [a] pyrene in four cell lines with differing metabolic capacity. Mutat Res 808:8-19

Shah UK, de Oliveira Mallia J, Singh N, Chapman KE, Doak SH, Jenkins GJ (2018) A three-dimensional in vitro HepG2 cells liver spheroid model for genotoxicity studies. Mutat Res/Genet Toxicol Environ Mutagen 825:51-58

Steiblen G, van Benthem J, Johnson G (2020) Strategies in genotoxicology: acceptance of innovative scientific methods in a regulatory context and from an industrial perspective. Mutat Res/Genet Toxicol Environ Mutagen 853:503171

Thybaud V, Aardema M, Casciano D, Dellarco V, Embry MR, Gollapudi BB, Hayashi M, Holsapple MP, Jacobson-Kram D, Kasper P (2007) Relevance and follow-up of positive results in in vitro genetic toxicity assays: an ILSI-HESI initiative. Mutat Res 633(2):67-79

Verma JR, Rees BJ, Wilde EC, Thornton CA, Jenkins GJ, Doak SH, Johnson GE (2017) Evaluation of the automated MicroFlow ${ }^{\circledR}$ and 
Metafer ${ }^{\mathrm{TM}}$ platforms for high-throughput micronucleus scoring and dose response analysis in human lymphoblastoid TK6 cells. Arch Toxicol 91(7):2689-2698

Wilde EC, Chapman KE, Stannard LM, Seager AL, Brüsehafer K, Shah UK et al (2018) A novel, integrated in vitro carcinogenicity test to identify genotoxic and non-genotoxic carcinogens using human lymphoblastoid cells. Arch Toxicol 92(2):935-951

Willems E, Leyns L, Vandesompele J (2008) Standardization of realtime PCR gene expression data from independent biological replicates. Anal Biochem 379(1):127-129

Youngblom JH, Wiencke JK, Wolff S (1989) Inhibition of the adaptive response of human lymphocytes to very low doses of ionizing radiation by the protein synthesis inhibitor cycloheximide. Mutation Research Letters 227(4):257-261
Yue W, Yager JD, Wang J-P, Jupe ER, Santen RJ (2013) Estrogen receptor-dependent and independent mechanisms of breast cancer carcinogenesis. Steroids 78(2):161-170

Zaïr ZM, Jenkins GJ, Doak SH, Singh R, Brown K, Johnson GE (2011) $\mathrm{N}$-methylpurine DNA glycosylase plays a pivotal role in the threshold response of ethyl methanesulfonate-induced chromosome damage. Toxicol Sci 119(2):346-358

Publisher's Note Springer Nature remains neutral with regard to jurisdictional claims in published maps and institutional affiliations. 